\title{
Metoda dialogów wizualno-werbalnych w terapii z dzieckiem z niepełnosprawnawnością w wieku wczesnoszkolnym. Analiza indywidualnych przypadków
}

W niniejszym artykule chcę pokazać, na podstawie analizy indywidualnych przypadków, a także semiotycznej analizy wytworu, potencjał: komunikacyjny, semiotyczny i terapeutyczny, stworzonej przeze mnie metody wizualno-werbalnej, która wpisuje się w znany już od dawna kierunek arteterapeutyczny. Zajmując się rysunkiem dziecka (Karczmarzyk 2011a, 2014b), znaczeniami dzieci i dorosłych na temat ikonografii malarstwa polskiego oraz europejskiego (Karczmarzyk, Wasilewska 2015), czy też ideą emancypacyjną rysunku dziecka (Karczmarzyk 2012), emancypacją w sztuce (Karczmarzyk 2015), kontynuuję swoje rozważania, otwierając się na poszukiwanie szerszego kontekstu (Karczmarzyk 2018) dotyczącego pedagogiki specjalnej i terapii. Metodą wykorzystaną w badaniu jest analiza indywidualnych przypadków, zaś oprócz techniki wywiadu stosuję również analizę semiotyczną, powstałego w trakcie badania, wytworu plastycznego (Rose 2010) oraz opis sesji arteterapeutycznej, która przebiega z wykorzystaniem metody dialogów wizualno-werbalnych.

Słowa kluczowe: metoda dialogów wizualno-werbalnego, dziecko z niepełnosprawnością, dialog, emancypacja rysunku dziecka

\section{The method of visual-verbal dialogues in the therapy with a disabled child in early education. Case studies}

In this article, I would like to show, based on the analysis of three individual cases, the communication, semiotic and therapeutic potential of the method of visual-verbal dialogues. Dealing with child's drawing (Karczmarzyk 2011a, 2014b), meanings of children and adults about the iconography of Polish and European painting (Karczmarzyk, Wasilewska 2015), or the idea of emancipation of child's drawing (Karczmarzyk 2012), emancipation in art (Karczmarzyk 2015) I continue my considerations, opening myself to seeking a broader context (Karczmarzyk 2018) regarding special pedagogy and therapy. The method used in this study is s case studies, and in addition to the interview technique, I also use a semiotic analysis of the drawings created during the study (Rose 2010), as well as a description of the art therapy session that uses the method of visual-verbal dialogues.

Keywords: method of visual-verbal dialogues, disabled child, dialogue, emancipation of a child's drawing 


\section{Wprowadzenie do problematyki rozważań}

W niniejszym artykule chciałabym pokazać, na podstawie analizy kilku indywidualnych przypadków (dialog wizualno-werbalny matki i jej dziewięcioletniego syna z zespołem Aspergera, dialog wizualno-werbalny pedagoga specjalnego $\mathrm{z}$ chłopcem $\mathrm{w}$ wieku pięciu lat, u którego zdiagnozowano zespół Aspergera, ADHD i zaburzenia integracji sensorycznej, oraz dialog wizualno-werbalny pedagoga specjalnego z dziewczynką $\mathrm{w}$ wieku pięciu lat0 z niepełnosprawnością wzrokową), potencjał: komunikacyjny, semiotyczny i arteterapeutyczny, stworzonej przeze mnie metody dialogów wizualno-werbalnych.

Teoretycznym backgroundem dla stworzenia metody była - z jednej strony koncepcja "dialogu bez arbitra" Joanny Rutkowiak (Rutkowiak 1992), a z drugiej praktyczna próba odnalezienia płaszczyzny wspólnych znaczeń, które tworzą się w trakcie dialogu, jakby na zasadzie „innego języka”. Filozoficznie rozumiejąc ten dialog jako właśnie „inny język”, bliskie mi są również rozważania Edwarda Soji (Soja1996) dotyczące "trzeciej przestrzeni", w której jest możliwe budowanie wspólnej płaszczyzny porozumienia. Moje badania dotyczące głosu rysunkowego dziecka i komunikacji dziecko-dorosły (Karczmarzyk 2011a i 2014b), a także projekty oraz interwencje pedagogiczne związane z dialogami rysunkowymi i malarski$\mathrm{mi}$, to próby poszukiwania polisemiotycznego języka opartego na wizualizacji, który może być wieloznaczny, szerszy od zwykłej werbalizacji i terapeutyczny.

Metoda oraz zaprezentowane $w$ tym artykule badania wpisują się w kierunek arteterapeutyczny, który mimo początkowych kontrowersji, budzi obecnie zainteresowanie wśród wielu pedagogów i terapeutów. Jak pisze Edyta Nieduziak: „Arteterapia jest obecnie jednym z najpopularniejszych kierunków studiów wśród pedagogów, a także osób zajmujących się terapeutyką i wychowaniem. Zainteresowanie to wynika z coraz częstszego wykorzystania sztuki oraz procesu twórczego do pracy nad rozwojem osobowości, jak też do korekty zachowań, rehabilitacji oraz psychoterapii" (Nieduziak 2012: 65).

Arteterapia jest to terapia $\mathrm{z}$ wykorzystaniem sztuki, a konkretnie chodzi tu o ekspresję artystyczną, w której nie jest istotne końcowe dzieło, ale sam proces twórczy, który dzieje się w trakcie sesji arteterapeutycznej (Karolak, Kaczorowska 2008). Arteterapia korzysta z takich technik plastycznych, jak: rysunek, malarstwo, rzeźba, grafika, fotografia. Podczas sesji arteterapeutycznej istotne są doświadczenia wewnętrzne pacjenta, sposób jego odczuwania, widzenia przezeń świata albo własnych problemów. 


\section{Metoda dialogów wizualno-werbalnych - założenia teoretyczne}

Metodę dialogów wizualno-werbalnych stworzyłam na potrzeby projektu artystycznego realizowanego przeze mnie od 2016 roku pod nazwą „ dialogi malarskie". Początkowo projekt ten zakładał pracę z artystami, jednak z biegiem czasu w swojej praktyce pedagogicznej zauważyłam, że wpływa on rozwijająco, terapeutycznie i twórczo również na takie grupy, jak: tutorzy, nauczyciele akademiccy, nauczyciele wczesnej edukacji, wychowawcy przedszkolni, ale również dzieci $\mathrm{w}$ wieku przedszkolnym, wczesnoszkolnym i dzieci niepełnosprawne pracujące $\mathrm{w}$ dialogu z osobami dorosłymi.

Zajmując się rysunkiem dziecka (Karczmarzyk 2011a, 2014b), znaczeniami dzieci i dorosłych na temat ikonografii malarstwa polskiego oraz europejskiego (Karczmarzyk, Wasilewska 2015), ideą emancypacyjną rysunku dziecka (Karczmarzyk 2012), czy też emancypacją w sztuce (Karczmarzyk 2015), postanowiłam kontynuować swoje rozważania, otwierając się na poszukiwanie szerszego kontekstu dotyczącego pedagogiki specjalnej i terapii.

W stworzonej przeze mnie metodzie chodzi o wspólne wykonywanie jednej pracy plastycznej, symultanicznie. Proces trwa tyle czasu, ile potrzebują uczestnicy i kończy się w momencie aż jedna z osób będzie chciała zakończyć daną pracę, a druga osoba z zespołu pozwoli na to. W trakcie powstawania pracy współautorzy rysują, rozmawiają i poznają siebie nawzajem. Negocjacja i wymiana myśli, poprzez werbalizację i wizualizację, staje się również formą samo-poznania. Tłumaczenie komunikatów oraz ich "przekład” na język werbalny jest bowiem swego rodzaju auto-komunikatem (Łotman 1999) dla każdego uczestnika dialogu.

Metoda stwarza również możliwość terapeutyczną. Poznanie dotyka bowiem sfery intymnej: emocji, problemów i lęków. W zależności od tego jak głęboko wejdziemy w dialog z drugą osobą i jak go poprowadzimy, możemy oczekiwać różnych wyników danej sesji.

Może skłaniać również do negocjacji znaczeń rysunkowych partnerów, którzy werbalnie mają problemy z porozumieniem się. Może być terapią i formą komunikacji z otoczeniem zewnętrznym oraz znaczącymi innymi. Jako dialog osób należących do odmiennych światów społecznych, może stanowić przestrzeń tworzącej się w ten sposób płaszczyzny i wspólnoty.

Pedagogicznym i jednocześnie terapeutycznym namysłem na temat opisywanej tutaj metody jest aktywny odbiór sztuki za pośrednictwem jej współtworzenia. Tak rozumiana działalność społeczna i edukacyjna, zwana „pedagogią interwencji" (Melosik, Szkudlarek 2010) jest bliska procesowi wzmocnienia jednostki w działaniach samostanowienia, samo-decydowania, współodpowiedzialności 
(Karczmarzyk 2015). Dlatego działanie malarskie w formie dialogu może być alternatywną auto-terapią dla jego uczestników. Nie jest w nim bowiem istotny produkt, ale sama aktywność twórcza. Poza tym tego rodzaju działanie przełamuje bariery językowe, komunikacyjne i społeczne. Zmieniają się role, a dialog dorosłego i dziecka staje się partnerski. Staje się on po prostu "dialogiem bez arbitra" (Rutkowiak 1992).

\section{Założenia metodologiczne}

Badanie w niniejszym projekcie oparte jest na metodologii jakościowej, dlatego też nie staram się robić przed-założeń, które mogłyby wykrzywić moje dążenia badawcze. Wybrane przeze mnie podejście jakościowe ma swoje uzasadnienie. Chodzi mi o głębsze wniknięcie w analizowane przeze mnie przypadki, które dobieram według stopnia niepełnosprawności dziecka, biorącego udział w sesji dialogu wizualno-werbalnego z dorosłym opiekunem.

Metodą wykorzystaną w badaniu jest analiza indywidualnych przypadków, która opiera się na poznaniu jednego bądź kilku przypadków, z uwzględnieniem różnych kontekstów i rozmaitych technik (Pilch, Bauman 2001). W badaniu, oprócz techniki wywiadu pogłębionego (Pilch, Bauman 2001: 327), stosuję też analizę semiotyczną powstałego w trakcie badania wytworu plastycznego (Rose 2010), a także opis sesji arteterapeutycznej, która przebiega z wykorzystaniem metody dialogu wizualno-werbalnego.

Analizę semiotyczną wytworu plastycznego przeprowadzę, uwzględniając: treść, znaczenia, kolorystykę (barwa, nasycenie, wartość), kontrast, organizację przestrzenną, zawartość ekspresyjną (Rose 2010).

W niniejszym badaniu analizuję następujące przypadki:

1. dialog wizualno-werbalny matki i jej dziewięcioletniego syna z zespołem Aspergera $(\mathrm{M}+\mathrm{S} 9)$;

2. dialog wizualno-werbalny pedagoga specjalnego $\mathrm{z}$ chłopcem $\mathrm{w}$ wieku pięciu lat, u którego zdiagnozowano zespół Aspergera, ADHD, zaburzenia integracji sensorycznej $(\mathrm{P}+\mathrm{CH} 5)$;

3. dialog wizualno-werbalny pedagoga specjalnego z dziewczynką $\mathrm{w}$ wieku pięciu lat z niepełnosprawnością wzrokową ( $\mathrm{P}+\mathrm{DZ} 5)$.

Imiona dzieci i dorosłych, ze względu na anonimowość badania, zostały zmienione. 


\section{Dialogi wizualno-werbalne - analiza indywidualnych przypadków}

\section{Przypadek 1}

Dialog wizualno-werbalny matki i jej dziewięcioletniego syna Adama z zespołem Aspergera

Kobieta prowadząca dialog jest profesjonalistką w swoim zawodzie, a także matką chłopca z zespołem Aspergera. Adam lubi książki fabularne i komiksy o tematyce fantazy. Lubi rysowaći tworzyć gry z postaciami, a także zmieniać je i tworzyć własne historie.

Pierwszym etapem badania było przygotowanie chłopca do dialogu. Został on uprzedzony, że będzie to wspólna praca, a zarówno technika, jak i temat tej pracy, są dowolne. Praca powstała w technice mieszanej: pisaki, kredki ołówkowe i pastele.

Praca została namalowana 15 kolorami, na białej kartce formatu A3 na planie pionowym. Tło zostało pokolorowane kredką ołówkową w kolorze jasnej zieleni. Centralnym punktem pracy jest wielka czerwona twarz stwora, który przypomina biedronkę. Obok tej latającej głowy, w górnej części kartki widać mrówki, biedron$\mathrm{ki}$, osę oraz innego rodzaju owady. W dolnej części pracy powstał świat czołgów, broni, potworów i samochodów. Interesującym elementem kompozycyjnym jest narysowana ścieżka złożona ze śladów w kolorze czarnym.

Całość przedstawienia jest bliska ilustracji komiksowej. Ta stylistyka prawdopodobnie została narzucona przez dziecko, bo z wywiadu matki wiadomo, że chłopiec interesuje się komiksem. Nasycenie pracy jest intensywne, a mocne odcienie kolorystyczne stworzone za pomocą pisaków, bywają przeplatane delikatnymi barwami rysowanymi kredkami ołówkowymi.

Z kolei organizacja przestrzenna pracy jest utrzymana w pewnym chaosie. Brakuje planów, a elementy małe przeplatają się z wielkimi. Nie ma tutaj miejsca na przestrzeganie kanonów kompozycyjnych. Interesujący w pracy jest jednak pewien podział. $W$ górnej części mamy świat natury: owady i kwiaty, a w dolnej części widać tematykę wojenną, nawiązującą do świata broni, walki, potworów. Nie trudno się domyślić, że autorem wojennych elementów jest chłopiec. Matka zaś tworzy znaki nawiązujące do rzeczywistości (Karczmarzyk 2014). Wprowadza ona również, może nawet nieświadomie, elementy dekoracyjne, które mają podkreślić walory estetyczne pracy plastycznej.

Chłopiec odpowiada na narysowane elementy przez kobietę walką, starając się je po swojemu "unicestwić", „zwalczyć". Oto co na ten temat mówi matka chłopca:

(...) wlał lawę do strumienia, postraszył mrówkę mieczem, na drugą biedronkę wystat Terensa z Angry Bird, na motyla nasłał żuko-bizona, nie zapomniał też o dynamicie i bazucie. 
Dzięki intensywnej kolorystyce oraz zastosowaniu linii, zawartość ekspresyjna pracy plastycznej jest wysoka. Widać również emocje namalowanych postaci. Jednak rzadko są one pozytywne. Chłopiec stara się raczej, aby jego postaci były groźniejsze, i jak mówi matka: „w jego mniemaniu - lepsze”. Starcie postaci rysowanych przez matkę z postaciami chłopca, w którym znaki nawiązują do znanych dziecku animacji np. „Angry Bird”, jest strategią walki chłopca o przywództwo.

Oto jak opisuje powstawanie pracy plastycznej kobieta prowadząca dialog wizualno-werbalny:

Zaczętam rysować biedronkę idaca w stronę jego kartki, a raczej w stronę, po której siedziat; Adam uznat że jest to zachęta do narysowania czegoś co będzie przeciwieństwem i powstata pierwsza rakieta, i ta tendencja towarzyszyła nam już do końca; podczas rysowania Adam caly czas komentowat to co się dzieje, zdarzato mu się dorysowywać coś do mojej części pracy i uznat, że jest to walka między moimi a jego stworami. Chciat tę walkę koniecznie wygrać (...). Rysowat dużo szybciej ode mnie, ostatecznie jego część pracy zajęta zdecydowanie większa część przestrzeni.

Interesująca w tym fragmencie opisu jest obserwacja matki, która stwierdza: "chciał tę walkę koniecznie wygrać".

W tym miejscu istotne wydaje się podkreślenie rywalizacji, która dokonuje się pomiędzy matką a synem, na podłożu walki o władzę. Jest to rodzaj napięcia pomiędzy osobą dorosłą, dominującą z racji swojej pozycji, a dzieckiem - osobą podporządkowaną. Ciekawa jest $\mathrm{w}$ tym przypadku zamiana ról. Syn, który chce być liderem pracy, może nim być na płaszczyźnie rysunkowej. Zatem rysunek staje się możliwością emancypacyjną dla dziecka. W przypadku wspólnego rysowania bowiem dziecko może mieć wreszcie przewagę nad rodzicem i może swobodnie wyrażać swoją silną osobowość.

Można w tym miejscu odnieść się również do teorii psychoanalitycznej np. Freuda. Jego teoria dotycząca kompleksu Edypa może wyjaśniać ten fenomen od strony psychologicznej. Koncepcja zwana „Kompleksem Edypa” pochodzi z mitu Sofoklesa, z klasycznej greckiej mitologii. Chodzi w niej o to, że każdy chłopiec przechodzi przez etap odczuwania pociągu seksualnego do matki i staje się naturalnym rywalem ojca (Freud 2010). W tym przypadku próba dominacji syna nad matką może mieć tego rodzaju nieświadome, seksualne odniesienie.

Kolejny, warty zwrócenia, element $\mathrm{w}$ analizowanym tutaj dialogu wizualnowerbalnym matki i syna to wiedza, którą nabywa kobieta o swoim dziecku, dzięki wspólnemu malowaniu. Oto co mówi ona o wspólnej pracy:

(...) praca była zabawna, poznałam mnóstwo obcobrzmiących pojęć, poznałam nazwy różnych dziwnych stworów.

Kobieta miała satysfakcję z pracy, a jednocześnie dowiedziała się czym interesuje się jej syn, co wie na różne tematy i jakie filmy zna i ogląda. Warto przeanalizować taki wspólny dialog pod kątem potencjalnej możliwości pedagogiczno- 
komunikacyjnej. Dziecko w dialogu wizualno-werbalnym opowiada dorosłemu o swoim świecie, swoich lękach i pasjach. W tym przypadku nie tylko wyraża się poprzez język wizualny, ale również werbalnie tłumaczy matce, kim są narysowane postaci.

Otwarcie się obydwu uczestników dialogu na możliwości, które daje metoda dialogu wizualno-werbalnego, jest istotne również z punktu widzenia terapeutycznego. Jak pisze A. Czajkowska: „Język werbalny pozostaje nadal zwyczajową formą, w jakiej komunikujemy nasze wewnętrzne myśli i uczucia innym, a czasami także sobie samym, słowa są po prostu sposobem nazywania i przedstawiania rzeczywistości. Nie wszystkie jednak doświadczenia i uczucia mogą zostać «przetłumaczone» na warstwę werbalną i dokładnie w niej wyrażone. Właśnie wtedy, gdy te doświadczenia i uczucia wymagają swoistego «tłumaczenia» ustanawiane są niezbędne «narzędzia» (...), które (pozwalają - MK) na rzeczywiste przedstawienie doświadczenia lub uczuć, które nie będą tłumione przez ramy języka" (Czajkowska 2019: 48).

\section{Przypadek 2}

Dialog wizualno-werbalny pedagoga specjalnego z chłopcem w wieku pięciu lat, u którego zdiagnozowano zespół Aspergera, ADHD, zaburzenia integracji sensorycznej (P+CH5).

Marek jest chłopcem bardzo ruchliwym i aktywnym, chętnie się wypowiadającym. Często prezentuje zachowania niepożądane oraz ma trudności z funkcjonowaniem $\mathrm{w}$ grupie rówieśniczej. Propozycja terapeutki, która zaproponowała dialog wizualno-werbalny chłopcu, została przyjęta przez niego z entuzjazmem. Dialog przeprowadzono w ramach zajęć edukacyjno-terapeutycznych.

Pracę wykonano na planie poziomym kartki A3, kredkami pastelowymi. Użyte kolory to: niebieski, zielony, czarny, czerwony, fioletowy, żółty i brązowy.

Pierwszym znakiem rysunkowym rzucającym się w oczy odbiorcy jest wielki zielony dinozaur, umieszczony w dolnym rogu kartki. Obok widać inne stworzenia latające. Tytuł pracy „Era dinozaurów” tworzy enklawę semiotyczną, czyli formę rysunkową, w której oprócz znaków rysunkowych widnieje inny system znakowy (Wallis 1983) - tutaj alfabet, umieszczony przez współautorów pracy.

Rysunek zachowuje tradycyjny podział kompozycyjny na pas ziemi i nieba. Widnieje w niej porządek. Wszystkie elementy są ze sobą w zgodzie i pasują do siebie. Nasycenie kolorystyczne nie jest zbyt intensywne, a niebieskie tło, wprowadzone do całości pracy, nadaje jej charakter estetyczny. Dodatkowo na rysunku można odnaleźć plany przestrzenne, które wzbogacają całość przedstawienia.

Chłopiec wyszedł z inicjatywą tematu pracy i zaproponował tytuł „Era dinozaurów". Jego pierwszym znakiem rysunkowym był latający dinozaur - ptero- 
daktyl. Oto jak opowiada o tej pracy pedagog specjalna, prowadząca wspólny dialog z chłopcem:

Ja zaczętam się włączać, natomiast próbowałam malować w innym miejscu, niż on, tak aby zapobiec wybuchowi ztości. Na samym początku (Markowi-MK) nie spodobało się to, co robię, ale po chwili powiedziat, że to sa mate stegozaury. On w tym czasie malowat pterodaktyla.

Warto w tym miejscu zwrócić uwagę, na elastyczną postawę pedagożki. Nie próbuje ona niczego narzucać swojemu współautorowi i czeka na jego inicjatywę. Ten rodzaj otwarcia się dorosłego i wręcz podporządkowanie się dziecku, przynosi bardzo dobry wynik. Chłopiec bowiem w czasie pracy plastycznej zabiera głos, i tak oto mówi o swoim rysunku:

\section{(...) to jest przodek ptaka, bo ma btony i umie latać (...), pterodaktyl nie ma zębów, ale je ryby.}

Chłopiec ujawnia ogromną wiedzę na temat, który jest dla niego ważny. Staje się ekspertem, ale również opowiada dorosłej osobie o swoich planach, marzeniach na przyszłość: „(Marek-MK) opowiadał, że będzie paleontologiem, powiedział, że jest to jego marzenie".

Jak widać, za pośrednictwem pracy plastycznej można dowiedzieć się więcej nie tylko o dziecku, ale też o jego marzeniach, które nie są $\mathrm{w}$ tym przypadku światem fikcyjnym, ale bardzo realnym planem na życie w przyszłości.

Interesujące jest, że chłopiec zwykle nie dopuszcza do swoich pracy innych. Woli pracować sam i zwykle niechętnie reaguje na pracę z osobą dorosłą. Oto, co mówi pedagog na ten temat:

(...) należy do dzieci, które niechętnie chca podejmować aktywność, zwtaszcza z osobą dorosta, a tym bardziej wspótpracować (...). Zazwyczaj (Marek-MK) do swoich rysunków nikogo nie dopuszcza, a jeśli nawet chce z nim ktoś wspólnie malować, kończy się to wybuchem złości.

Kolejny istotny etap sesji arteterapeutycznej to obserwacja pedagoga, która ujawnia cechy badanego chłopca. Ze względu na jego zaburzenie - zespół Aspergera, który należy do łagodniejszych form autyzmu, jego ciągła potrzeba kontroli częste monologi i zanudzanie innych swoimi wycinkowymi zainteresowaniami, czy też trudności dotyczące wzajemności w komunikacji, są typowymi objawami dziecka z autyzmem w wieku przedszkolnym (Jagielska 2010).

Zaskakujące jest więc działanie metody dialogu wizualno-werbalnego, dzięki której pedagog dociera do dziecka, motywuje je do współpracy i komunikuje się z nim, zadając mu pytania w trakcie wspólnej pracy rysunkowej.

Oto co mówi na ten temat pedagog:

(...) naprawdę udato mi się zbudować wspólny i ciepty dialog, wypracować kompromis. Chwilami jego wyraz twarzy podpowiadat mi, że on użybby innego koloru w tym miejscu. (...) A mimo to (...) nie zezłościt się, starat się zaakceptować, a poprzez ciągte moje zadawanie pytań (...) miat 
poczucie, że to on decyduje i ma możliwość decydowania oraz poczucie kontroli nad tym co się dzieje w danym momencie.

\section{Przypadek 3}

Dialog wizualno-werbalny pedagoga specjalnego z dziewczynką $\mathrm{w}$ wieku pięciu lat $\mathrm{z}$ niepełnosprawnością wzrokową (P+DZ5).

Dialog wizualno-werbalny odbył się pomiędzy pedagogiem a dziewczynką w wieku pięciu lat o imieniu Ania, która ma niepełnosprawność wzrokową (głęboka krótkowzroczność -18 dioprii). Dziecko jest radosne, ruchliwe i lubi dominować w grupie.

Praca została wykonana farbami, na planie pionowym kartki B1. Użyte kolory to: niebieski, zielony, żółty i czerwony.

Organizacja przestrzenna pracy jest utrzymana w pewnym planie. Początkowym etapem dialogu wizualno-werbalnego było ustalenie tematu wspólnej pracy. Taka początkowa wymiana myśli i wspólne ustalenia dotyczące pracy, są bliskie współtworzeniu reguł, którymi należy się posługiwać np. w danej społeczności. Ustalanie pewnych regulacji pomaga zbiorowości przetrwać, komunikować się wzajemnie i współpracować (Ziółkowski 1989).

W kolejnym etapie wspólnej pracy pedagog daje możliwość decydowania o pracy plastycznej swojej współautorce. Oto wypowiedź kobiety:

Podczas wspólnego malowania na początku starałam się podążá za dziewczynka i pytać się co mam teraz malować. (Ania - MK) chętnie mi opisywała co mam robić. (...) Aby sprowokować dziewczynkę, zamalowałam na jeden kolor główna część pracy - twarz potwora. (Ania - MK) trochę była zaskoczona, ale spokojnie stwierdziła, że jak wyschnie farba, to na nowo domalujemy mu twarz.

Interesująca w tej wypowiedzi jest konsekwencja dziewczynki, która dąży do wykonania pracy według własnego pomysłu. Przyjmuje odmienne znaki rysunkowe osoby dorosłej, ale tylko w obrębie swojej idei. Stara się tłumaczyć i nakłania współautorkę do działania według własnej wizji. Widać tutaj oczywiste skłonności do przywództwa i silny charakter dziecka. Tego rodzaju cecha może wynikać z trudnych zadań i codziennych problemów w otoczeniu zewnętrznym, z którymi musi sobie radzić niepełnosprawne dziecko. Niedowidzenie dziewczynki, zmusza ją bowiem do pokonywania barier $\mathrm{w}$ trakcie naturalnych, codziennych czynności, z którymi osoby zdrowe nie mają problemów. Mimo że w Polsce coraz więcej instytucji zabiega o przystosowanie warunków do potrzeb osób niedowidzących, ciągle jeszcze infrastruktura miasta wymaga ulepszeń i udoskonaleń.

Kolejny etap wspólnego malowania jeszcze bardziej uwidacznia cechy osobowościowe dziewczynki: 
Dalszy etap wspólnego malowania wygladał tak, że wybierałam inne kolory niż oczekiwała tego dziewczynka, zaproponowałam również zmianę tematu pracy. (Ania-MK) na każdą moja propozycję się zgadzała (...), najbardziej emocjonalnym momentem dla (Ani-MK) było to, że "potworowi" domalowałam więcej niż jedna nogę. Dziewczynka w tym momencie krzyczała "ej" i uderzała ręką o stót.

W powyższym fragmencie wypowiedzi element emocjonalny, który opisuje pedagożka prowadząca dialog z dziewczynką, jest związany z gwałtowną reakcją dziecka. Uderzanie w stół pięścią jest elementem agresji. Według J. Dollarda istnieje związek zachowań agresywnych i przemocowych z niezaspokojeniem u jednostki ważnej potrzeby (Dollard 1939). Jak pisze E. Czemierowska-Koruba: "człowiek gotów jest posłużyć się agresją, jeśli spowoduje to usunięcie przeszkody w realizacji istotnego dla niego celu" (Czemierowska-Koruba 2015).

Badana dziewczynka posiada jednak nad wyraz rozwiniętą wyobraźnię, a także jest bardzo elastyczna w swojej wizji. Potrafi poradzić sobie z „błędem” współautorki. Ostatecznie wpada na pomysł zmiany namalowanych nóg na skrzydła rysowanego wspólnie potwora. Ten rodzaj negocjacji znaczeniowej jest dowodem na kreatywność i oryginalność myślenia dziecka. Dziewczynka nie poddaje się, a zamiast tego dostosowuje swoją wizję do możliwości, które w danym momencie posiada.

\section{Podsumowanie rozważań i wnioski z badań}

Analizowane w niniejszym rozdziale dialogi wizualno-werbalne skłaniają do przemyśleń natury pedagogicznej i psychologicznej.

Potencjał tego projektu pokazuje interesującą płaszczyznę możliwości dla dziecięcego rozwoju. Rysunek może być dla niego polem walki o bycie liderem w trakcie pracy plastycznej. Może skłaniać do komunikacji i negocjacji znaczeń rysunkowych z dorosłym. Może być terapią i formą komunikacji z otoczeniem zewnętrznym oraz znaczącymi innymi.

Metoda dialogów wizualno-werbalnych zwraca uwagę na możliwość porozumiewania się dziecka i dorosłego oraz poszukiwania innego języka, w którym może istnieć szersze pole interpretacji i kreowania znaczeń. „Obrazy zawierają (bowiem - MK) symbole wskazujące na rzeczy niewidoczne, także na te ukryte w głębszych warstwach umysłu. Podobnie jak sny są to wysoce twórcze konstrukcje, które przekazują szeroką gamę emocji, wspomnień, potrzeb i życzeń. W jednym obrazie może zostać skondensowanych wiele informacji, co czyni go istotnym sposobem reprezentowania tożsamości" (por.: Suler 2013 za: Czajkowska 2019: 50). 
Rysunek z dzieckiem niepełnosprawnym stymuluje jego rozwój i wymusza na nim komunikację, co w przypadku dzieci autystycznych jest bardzo trudne. Dlatego ten rodzaj działania wydaje się szczególnie znaczący dla pedagogiki specjalnej i powinien być szerzej stosowany.

Przedstawiona problematyka jest również istotna z perspektywy pedagogicznej. Zwrócenie uwagi na potencjał komunikacyjny dialogów wizualno-werbalnych jest ważne dla dziecka i rodzica, którzy w trakcie takiej pracy mogą nauczyć się siebie nawzajem. Zbyt często komunikacja dzieci i dorosłych bywa ograniczona, oparta na dyskursie władzy i wykluczania najmłodszych. W przypadku wspólnego dialogu wizualno-werbalnego role zostają zmienione. To dziecko otrzymuje władzę i możliwość kreowania światów według własnej idei. Rodzic w tym momencie uczy się podążać za wizją dziecka. W ten sposób następuje szukanie przestrzeni do negocjacji i uczenia się zasad oraz reguł w odmiennej formule.

\section{Bibliografia}

Eco U. (2008), Dzieło otwarte: Forma i nieokreśloność w poetykach wspótczesnych, Wydawnictwo W.A.B., Warszawa.

Freud S. (2010), Wstęp do psychoanalizy, Wydawnictwo Marek Derewecki, Kęty.

Czajkowska A. (2019), Fototerapia w pracy nauczyciela, pedagoga i terapeuty, Wydawnictwo Uniwersytetu Łódzkiego, Łódź.

Czemierowska-Koruba E. (2015), Agresja i przemoc w szkole. Co powinniśmy wiedzieć by skutecznie działać, Ośrodek Rozwoju Edukacji, Warszawa.

Dollard J., Miller N.E., Doob L.W., Mowrer O.H., Sears R.R. (1939), Frustration and aggression, Yale University Press, New Haven, CT, US.

Jagielska B. (2010), One są wśród nas. Dziecko z autyzmem i zespołem Aspergera w szkole i przedszkolu. Informacje dla pedagogów i opiekunów, Ośrodek Rozwoju Edukacji, Warszawa.

Karczmarzyk M. (2018), Dialogi równoległe. Wykorzystanie języka obrazu w spotkaniu tutoringowym [w:] B. Karpińska-Musiał, M. Panońsko (red.), Tutoring jako spotkanie. Historie indywidualnych przypadków, Wydawnictwo Wolters Kluwer, Kraków.

Karczmarzyk M. (2011a), Co znaczq rysunki dziecięce. Znaczenia i potencjał komunikacyjny rysunku dziecka sześcioletniego, Wydawnictwo Uniwersytetu Gdańskiego, Gdańsk.

Karczmarzyk M. (2014b), Co znaczą rysunki dziecięce, Wydawnictwo Anwi, Gdańsk.

Karczmarzyk M. (2015), Wspólnota i u(nie)pamiętnianie. Rewizualizacje, znaczenia i strategie budowy miasta w przestrzeni Gdańska [w:] M. Mendel (red.), Miasto jak wspólny pokój: gdańskie modi co-vivendi, Gdańskie Towarzystwo Naukowe, Instytut Kultury Miejskiej, Gdańsk.

Karczmarzyk M., Wasilewska A. (2015), Malarstwo w oczach dzieci. Znaczenia nadawane wybranym obrazom Salvadora Dalego, Pabla Picassa, Jacka Yerki, Kultura i Wychowanie nr 10(2), 36-43.

Karczmarzyk M. (2012), Prawo dziecka do "głosu" w przestrzeni społecznej. Rysowanie jako proces emancypacyjny, Problemy Wczesnej Edukacji nr 2(17), VIII, 116-122.

Karolak W., Kaczorowska B. (red.) (2008), Arteterapia w medycynie i edukacji, Wyższa Szkoła Humanistyczno-Ekonomiczna w Łodzi, Łódź. 
Łotman J. (1999), Kultura i eksplozja, Państwowy Instytut Wydawniczy, Warszawa.

Nieduziak E. (2012), Arteterapia - nowy obszar ksztatcenia pedagogów?, Pedagogika Szkoły Wyższej, 2, 65-84.

Pilch T., Bauman T. (2001), Zasady badań pedagogicznych. Strategie ilościowe i jakościowe, Wydawnictwo Żak, Warszawa.

Rose G. (2010), Interpretacja materiałów wizualnych. Krytyczna metodologia badań nad wizualnościa, Wydawnictwo Naukowe PWN, Warszawa.

Rutkowiak J. (1992), Pytanie, dialog, wychowanie, Wydawnictwo Naukowe PWN, Warszawa. Wallis M. (1983), Sztuki i znaki. Pisma semiotyczne, PIW, Warszawa.

Ziółkowski M. (1989), Wiedza, jednostka, społeczeństwo, PWN, Warszawa. 